\title{
VII. ブドゥ酒のフェノール性化合物
}

国税庁醇造試験所

大塚謙 一

ブドウ酒中に見出されるフェノール性化合物には simple phenolic compounds と flavonoids とがある。 これらはさらに次のよらに分けられる (SINGLETON \& ESAU')

Simple phenolic compounds

1. p-hydroxylated benzoic acid \& derivatives

2. $\quad$-hydroxylated cinnamic acid \& derivatives

3. non flavonoid phenols

Flavonoids

1. flavan-3-ols (catechins)

2. flavan-3,4-diols, anthocyanogens, condensed tannins

3. anthocyanins (pigments)

4. flavonols \& flavones

\section{I. ブドウ酒中の simple phenolic compounds の存在と由来}

\section{(1) p-Hydroxylated benzoic acids とその誘埒体} （第 1 表）

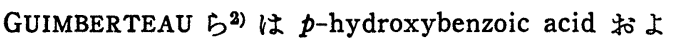
び syringic acidを同定し, RIBEREAU-GAYON ${ }^{3)}$ は vanillic acid, syringic acid, gentisic acid, protocatechuic acid, gallic acid の存在を報告している。し かしこれらは結合型で存在していて, 定量值は saponification 後の值となっている。これらは果皮に多く, Cabernet Sauvignon のブドウ酒では多いが, Sémillon のブドウ酒では全部で $1 \mathrm{mg} / \mathrm{l}$ 位である。元の形は flavonoid で，その分解により生成すると考えられてい る (gentisic acidの由来は不明)。このことは PIFFERI4) の実験でも裏書さされている。

malvidin $\longrightarrow$ syringic acid

peonidin $\longrightarrow$ vanillic acid

cyanidin $\longrightarrow$ protocatechuic acid

dalphinidin $\longrightarrow$ gallic acid

Salicylic acid は現在ではブドウ酒への添加は許され

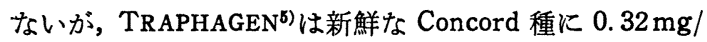
$\mathrm{kg}$ の存在を示し, その後の知見で自然に存在する salicylic acid の量は $1 \mathrm{mg} / l$ を超えないとされている。 WEBB ら ${ }^{6)}$ によれば Muscat の fusel oil 中に methyl salicylate, Sylvaner 酒に ethyl salicylate が見出さ れる。

PIFFERI ${ }^{4}$ は Merlot 酒に $\gamma$-resorcylic acid を定性 的に見出している。

Gallic acid について RIBEREAN-GAYON ${ }^{3)}$ は白ブド ウ酒で $0 \sim 0.5 \mathrm{mg} / l$, 赤ブドウ酒で $12 \mathrm{mg} / l$ (ケン化後) を定量し, HENNIG ら7) は発酵直後のものに遊離の gallic acidを見出し，熟成したものにはい。また，種 子の抽出物にも遊離型は見出されず (SINGLETON $\left.{ }^{8)}\right)$, エ ステル化した gallate のみである (DURMISHIDZE'))。

第1表 ブドウ酒中に見出されるフェノール化合物 (Simple phenolic compounds)

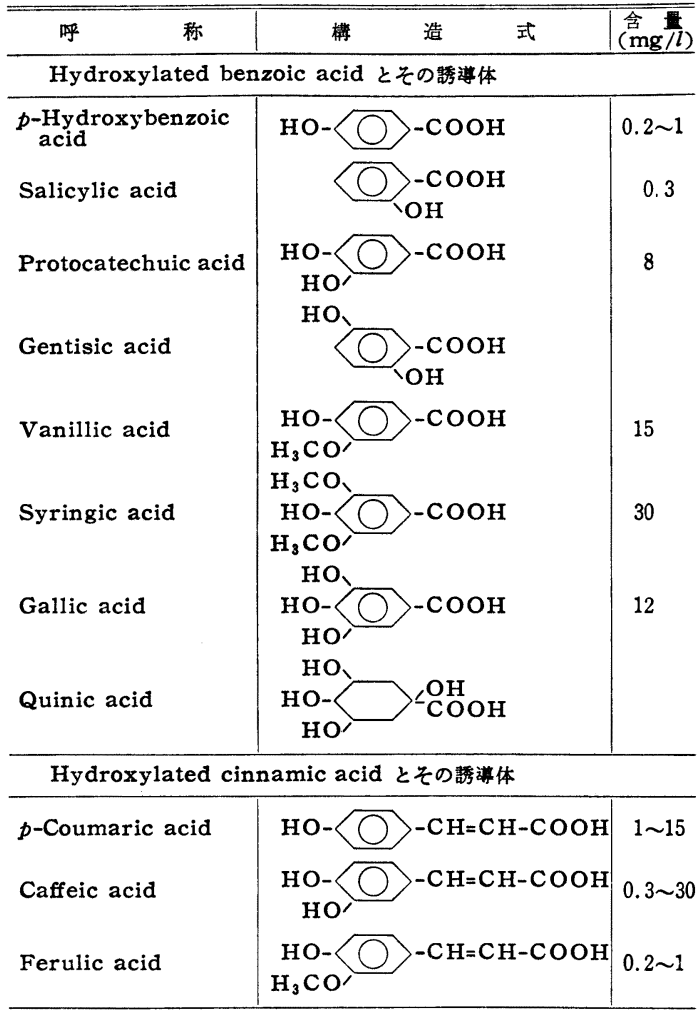


（2）Hydroxy cinnamic acid とその誘導体(第1表) p-coumaric acid と caffeic acid 拉よび誘導体がブ ドウに存在することは HENNIG ら7により報告され， RIBÉREAU-GAYON ${ }^{3)}$ は $p$-coumaric acid, $0.3 \sim 30 \mathrm{mg} / l$; caffeic acid, $1 \sim 15 \mathrm{mg} / l$ を定量している。Caffeic acid は植物体の普遍的成分であるが， cafferoyl quinate また は chlorogenate として存在することが多い。

Hydroxycinnamic acid はブドウ酒中に一部遊離型で 存在するようであるが，果粒中には結合型が多い (HENNIG7), RIBEREAN-GAYON ${ }^{3)}$ )。

Ferulic acid は 0.2〜1 mg/l といら少量で, sinapic acid の存在の有無には両説がある。

IBRAHIM $^{10)}$ は植物体から抽出, 分解の際に次の過程 があるために，研究者により結果が左右されるとした。

$p$-coumaric acid $\longrightarrow p$-hydroxybenzoic acid caffeic acid $\longrightarrow$ protocatechuic acid ferulic acid $\longrightarrow$ vanillic acid sinapic acid $\longrightarrow$ syringic acid

HENNIG ら ${ }^{7)}$ は chlorogenic acid と isochlorogenic acid の存在を示し, SONDHEIMER ${ }^{11)}$ は Steuben 種に chlorogenic acid, $140 \mathrm{mg} / 100 \mathrm{~g}$ 乾物; isochlorogenic acid, $2 \mathrm{mg} / 100 \mathrm{~g}$; neochlorogenic acid, $2 \mathrm{mg} / 100 \mathrm{~g}$ を 定量した。JURICS ${ }^{12)} は 125 \mathrm{mg} / \mathrm{l}$ の chlorogenic acid

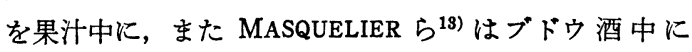
chlorogenic acid $50 \sim 150 \mathrm{mg} / \mathrm{l}$ 定量している。

Shikimic acid と quinic acid は多くの研究者がブド ウ及びブドウ酒中に見出している (KOHMAN ${ }^{14)}$, HENNING $5^{7)}$, CARLER $ら^{15)}$, Delmas ${ }^{16)}$, KLIEWER $\left.^{17)}\right)$ 。

MASQUELIER $ら^{13)}$ は feruloyl quinate MASQUELIER $5^{13)}$, BURKHARDT ${ }^{19)}$ は $p$-coumaroyl quinateの存在を報告したが,一方, RIBÉREAU-GAYON ${ }^{20)}$ はこれらは monocafferoyl tartrate monoferuloyl, mono-p-coumaroyl tartrate のように tartaric acid と 結合していると主張している。

大塚ら ${ }^{21)}$ は発酵中の結合型执よび遊離型フェノールを 測定し, 遊離型（p-coumaric acid）が增加するとした。

（3）その他の nonflavoid phenols

CHAUDHARY ら 22) は貴腐ブドウ酒で， $m$-cresol を見 出した。

HENNIG $ら^{7)}$ は vanilline, ellagic acid, ellagitannin 等の存在を報告したが，これらはタル材から由来したと 考えられる7。

この他, umbelliferone ( $p$-coumaric lactone), esculetin (caffeic acid 由来), scopoletin ठ見出されてい る。

また, tyrosine 拉よびその発酵生成物の tyrosol ${ }^{23)}$ が ある。tyrosol はブドウ酒の total phenol に占める率は 大きい。

\section{II. フトトウ酒中の Flavonoids の存在と由 来（いわゆる tannin 質）}

\section{(1) Catechin (Flavan-3-ols)}

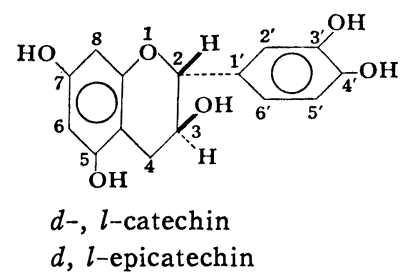

Catechin ととの epimerである epicatechinは 5,7， $3^{\prime}, 4^{\prime}$-tetrahydroxyflavan-3-ols であり, gallocatechin とその epimer である epigallocatechin は $5,7,3^{\prime}, 4^{\prime}$, 5'-pentahydroxyflavan-3-ols である。さらに 2 と 3 の 炭素は不斉炭素であるため, 立体異性体 (stereoisomer) が存在する。したがって, $d$-型, $l$-型拉よび $d, l$-型が ある。(……は紙面に対し下方，一は上方）

ブドウおよびブドウ酒の catechin 類については DURMISHIDZE 一派の著書がある9)。彼等の試料は始め 材料を蒸気に当て, 乾燥, 粉砕後, $\mathrm{CHCl}_{3}$ にて chlor phyll を除き, EtOAc に浸漬抽出し, 溶媒を除く。こ れに $\mathrm{CHCl}_{3}$ を加えて tannins を沈でんさせ, 上澄を濃 縮する。これから酶酸鉛沈でん法で $d$-catechin を分離 した。また鉛塩の分画により $d$-catechin gallateも分 離した。これらはブドウの葉, 果皮, 種子が材料となっ た。

この他に $l$-gallocatechin も同定された。このように して結局次のものが証明された。

$d$-catechin, $d l$-catechin, $d$-gallocatechin, $l$-gallocatechin, $d$-catechin gallate, $d$-epicatechin gallate。

LAVOLLAY 5 ${ }^{24)}$ はより以前にブドウおよび赤ブドウ 酒で catechin と epicatechin を報告しており, その後 HENNIG ら7) は汇紙クロマトグラフィーで Riesling 種 と若いブドウ酒中に $d$-catechin, $l$-epicatechin, $l$ epigallocatechin を示した。PIFFERI ${ }^{18)}$ は赤ブドウ酒で, $d$-gallocatechin gallate, $l$-gallocatechin, $d$-catechin, $l$-epicatechin を認めた。RIBEREAU-GAYON ら ${ }^{25)} は d$, l-gallocatechin をつけ加えた。

JURICS ${ }^{12)}$ は破さい果を煮沸し，この中に $d$-catechin を $101 \mathrm{mg} / \mathrm{kg}, l$-epicatechin $40 \mathrm{mg} / \mathrm{kg}$ 定量した。

(2) Flavan-3, 4-diols, Anthocyanogens (第 2 表) ROSENHEIM ${ }^{26)}$ は 1920 年にブドウの葉から分離 した ものに leuco-anthocyanins といら名を用い, これらは glycoside でなく，酸との加熱により赤変することから 
第 2 表 ブドウ酒中に見出される flavonoids

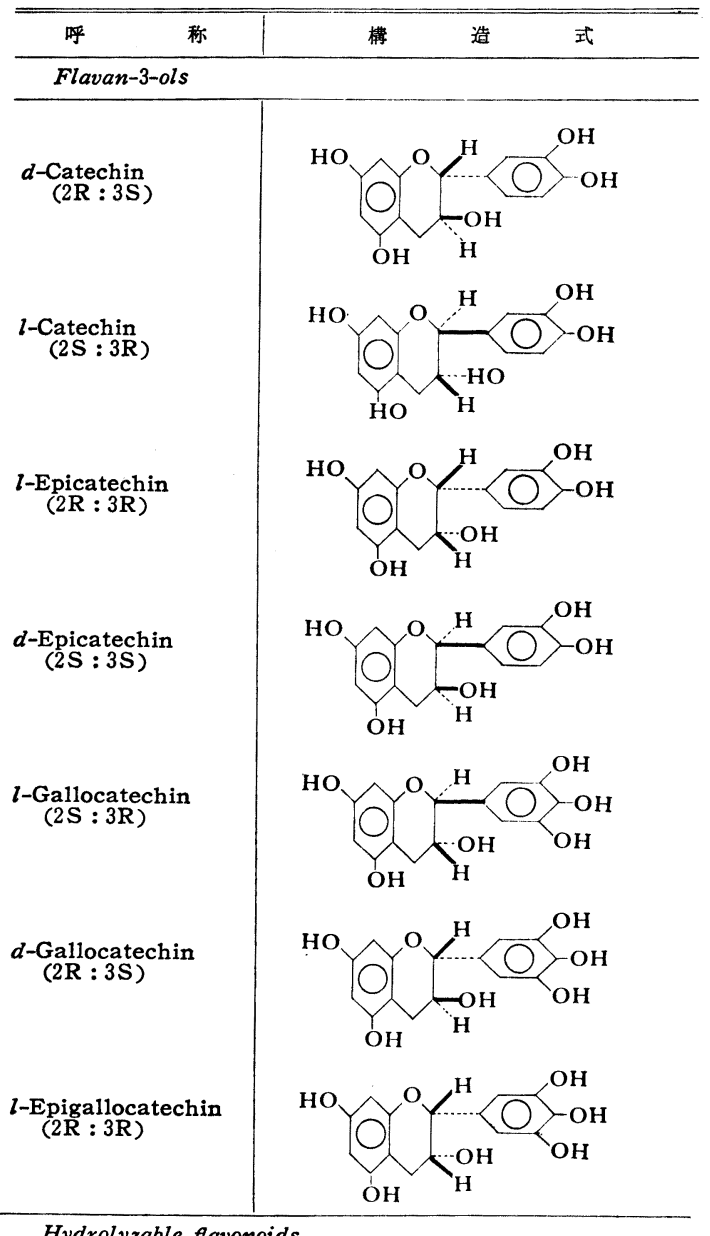

Hydrolyzable flavonoids

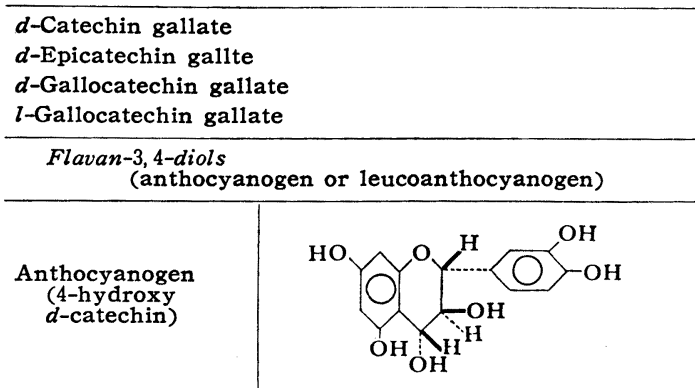

leucoanthocyanidins といわれ, anthocyanogens とも いわれてきている。

Antho cyanogens は構造単位として flavan-3, 4-diols をもち、これは catechins の第 4 炭素に $\mathrm{OH}$ 基がつい たものである $\left(5,7,3^{\prime}, 4^{\prime}\right.$-tetrahydroxy flavan-3,4diol)。

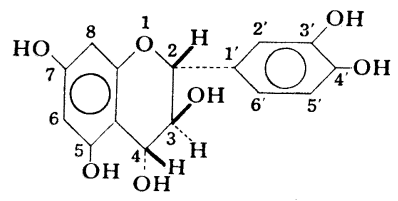

この構造は 3 個の不斉炭素が生じ, 8 個の異性体が存 在することになる。

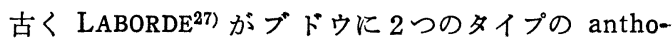
cyanogens があることを示している。濃アルコール可溶 と加水溶液にのみ可溶のものである。その後 COMBES ${ }^{28)}$ は amyl alcoholに溶かし，酸と加熱すると antocyanidin に変る物質を報告した。ROSENHEIM ${ }^{26)}$ は無色の物質つ まり leucoanthocyanidin は 3,4-dihydroxyflav-2,3-en に相当するとした。MASQUELIER $5^{29)}$ は $5,7,3^{\prime}, 4^{\prime}$ tetrahydroxyflavan-3,4-diol の構造を提出した。

Leucocyanidin は紫ブドウの果皮と種子に在ること， V. vinifera の葉と小枝には leucocyanidin と leucodelphinidin とが見出される。

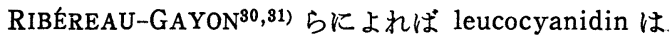
赤ブドウ酒の phenol 成分のらち主なもので, 果皮には 比較的少なく, 大部分は種子から由来する。したがって 果汁のみで造るブドウ酒には極めて少ない。

JOSLYNら ${ }^{32)}$ は種子から 2 つ, 果皮から 2 つの計 4 つ. の cyanidin を生成する anthocyanogens を得た。果 皮からの酢エチ可溶 leucocyanidin は熱酸性 butanol. で, cyanidin 以外に $d$-catechin, $l$-epicatechin, 不明物 を与える。また果皮からの butanol 可溶 leucocyanidin. は cyanidin と 57.5〜65.5\% の glucose となる。この ことは procyanidin diglucoside であることを示す。一 方, 種子からはメチル誘導体及び酢酸塩の結晶を得, 分 子量は約 1,400 と 700 とであった。果皮の leucoanthocyanidin は種子のものより分子量は大きいと考えら れている。つまり polymeric なるのがある。

RIBEREAU-GAYON ら ${ }^{33)}$ は酢エチ溶媒で沪紙クロマト で動くものは 2〜8 ケの leucoanthocyanidin polymer であるとしている。

ブドウおよびブドウ酒の tannin は古くから研究され. てきた。特に赤ブドウ酒の沾味のもとであり, gelatin と沈でんすること等から重要視された。

Tannins は FREUDENBERG ${ }^{34)}$ により, 被加水分解性 hydrolyzable のものと縮合型 condense のものと分け られた。前者は gallo tannic acid, 後者は condensed tannins または phlobatanninsである。Gallate はブド ウでは全フェノール物質の $5 \%$ 以下で, 葉, 果皮, 果梗 では極めて少ない。

Condensed tannin は加熱により褐色または赤褐色の 
第 3 表 ブドウ酒中に見出される Anthocyanins

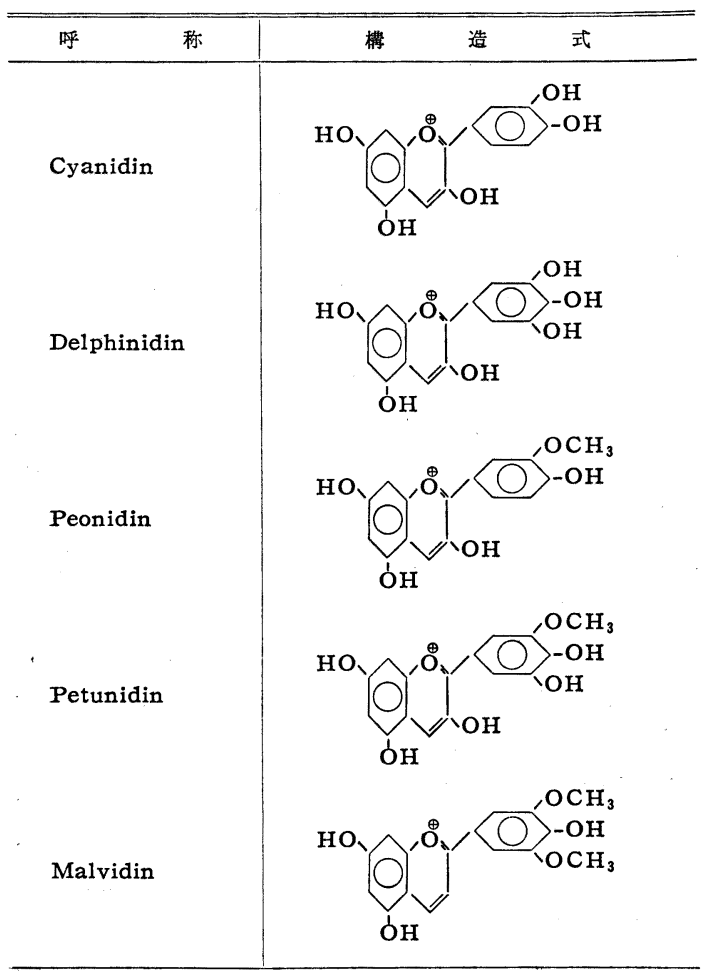

不溶性物 phlobaphene になる。種子からの酢エチ不溶 の phlobatannin の分子量は 5,300であり，酢エチ可溶 の lencoanthocyanin の分子量は 600 1,500 である。

（3）Anthocyanins（第 3 表）

ブドウの色素は古くから研究対象になっていたが，複 雑な構造と類似の化合物の混在のために長い間明らかで なかった。19 世紀の終りから 20 世紀初めにかけて，色 素の多様性とブドウの品種間に関係がありそらに思われ ていた。古くSOSTEGNI (1897) がブドウ色素のアルカ リ分解産物として pyrocatechol と phloroglucinol を 見出したことは構造解明の第一歩といえる。Willstätter 一派 ${ }^{35)}$ が結晶状に色素を分離し， dimethyl delphinidin 誘導体の monoglucoside と同定し，これを oenin と名 付けた。しかし 1931 年になって Levy ら malvidin-3- $\beta$-glucoside であることを合成して確めた。 その後各種のブドウから petunidin-3,5-diglucoside, delphinidin glucoside, cyanidin-3-glucoside, malvidin-3,5-diglucoside が見出された。

一般にブドウの anthocyanin として malvidin, delphinidin, cyanidin, petunidin, peonidin $か$, glucoside として見出されるが，RIBEREAU-GAYON ${ }^{37)}$ は $V$. vinifera と hybrid とで，10種の色素を見出し，その pattern が異なること，V. vinifera は diglucoside を
第4 表 V. vinifera と $V$. labrusca の anthocyanin

\begin{tabular}{|c|c|c|c|}
\hline \multicolumn{2}{|c|}{$\%$} & $V$. vinifera & V.labrusca \\
\hline Cyanidin & $\left\{\begin{array}{l}\mathrm{MG} \\
\mathrm{DG}\end{array}\right.$ & 3 & 5 \\
\hline Peonidin & $\left\{\begin{array}{c}\text { MG } \\
\text { DG }\end{array}\right.$ & 15 & $\begin{array}{r}10 \\
1\end{array}$ \\
\hline Delphinidin & $\left\{\begin{array}{l}\mathrm{MG} \\
\mathrm{DG}\end{array}\right.$ & 12 & 21 \\
\hline Petunidin & $\left\{\begin{array}{l}\text { MG } \\
\text { DG }\end{array}\right.$ & $\frac{12}{-}$ & 15 \\
\hline Malvidin & $\left\{\begin{array}{l}M G \\
D G\end{array}\right.$ & 35 & $\begin{array}{r}33 \\
2\end{array}$ \\
\hline Unknown & & 23 & 12 \\
\hline
\end{tabular}

含まないことを示した。しかし，その後多くの研究者に より種々の品種についてこの区別が正当かどうか報告さ れた。結局, 大多数のものには当てはまるが, 例外のあ ることもあるといわれる（第 4 表参照）。

さらに複雑なことは, 以上の遊離の glucoside の他に acyl 化した $p$-coumaroylまたは caffeoyl glucoside が存在する。

たとえば CHEN and LUH $^{38)}$ は V. rupestris $\times V$.vinifera 交配種で 18 ケの anthocyan を見出し, その多 い順から malvidin-3,5-diglucoside, p-coumaroyl malvidin-3, 5-diglucoside, $p$-coumaroyl malvidin-3glucoside, malvidin-3-glucoside, peonidin-3, 5-diglucoside, coffeoyl malvidin-3,5-diglucoside, peonidin3-glucoside, $p$-coumaroyl peonidin-3-glucoside, $p$ coumaroyl peonidin-3,5-diglucoside を示し, さらに cyanidin-3-glucoside, petunidin-3,5-diglucoside の存 在も認めている。

ALBACH ら ${ }^{39)}$ によれば平均の比率は $0.2 \%$ unknown, $3.4 \%$ delphinidin glucoside, $5.0 \%$ petunidin glucoside, $41.2 \%$ malvidin glucoside (plus cyanidin glucoside), $10.1 \%$ peonidin glucoside, $13.6 \%$ caffeoy 1 型, $26.5 \%$ p-coumaryl 型である。

これらの色素は主にブドウの果皮の抽出物で見出され ているが，ブドウ酒でも若い内は同様の色素が存在する といえるが, acyl 基は早急に失くなり，p-coumaric， caffeic acid は遊離する。また, glucoside も加水分解 されて遊離の anthocyanidin になる。一般にブドウ酒 中からの anthocyanidin は少量しか回收できないのは anthocyanin が重合した赤色タンニン様分子に移行する ためと考えられる。

（4） Flavonols, Flavones（黄色色素）(第 5 表）

NEUBAUER は 19 世紀末にすでにブドウの葉から quercetinを分離し, さらに quercitrin (quercetin-3rhamnoside) の存在も認めている。その後,ブドウ酒を 始め,ブドウに quercetinが含まれ，大部分は glycoside であることも知られた。 
第 5 表 ブドゥ酒中に見出される Flavonols およよび Flavones

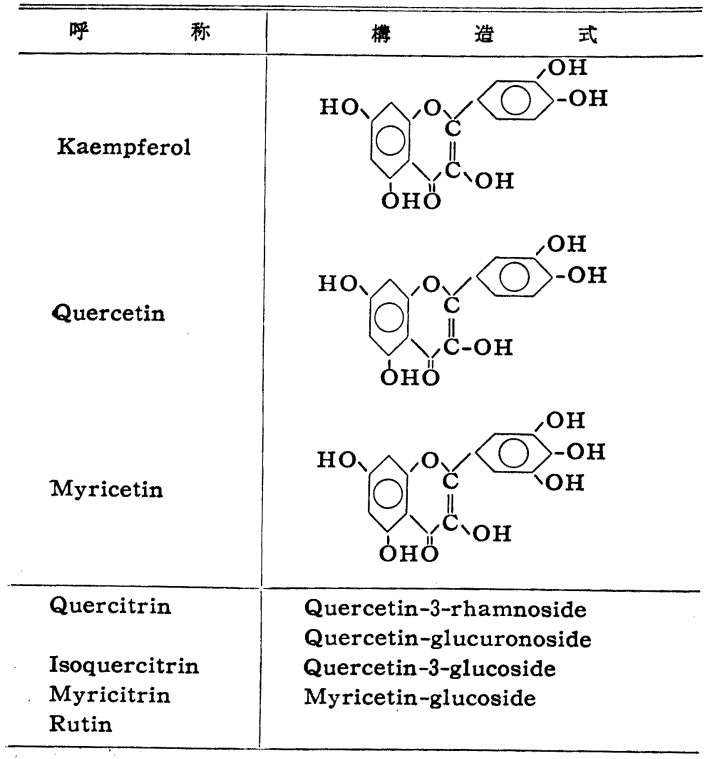

WILLIAMS and WEUDER ${ }^{40)}$ は各種のブドウに quercetin 以外飞 isoquercitrin (quercetin-3-glucoside) の 存在を証明し, MASQUELIER and POINT ${ }^{41)}$ はブドウ酒 中にもこのものを見出し，果皮に偏在するとした。 HENNIG ら7)はこの他に myricetinを報告した。 RIBEREAU-GAYON ${ }^{42}$ は果皮の酢酸エキル抽出物中に quercetin, kaempferol, myricetin の glucoside を見 出し,これらが3-glucosideでありこの他に quercetin -glucuronoside を証明した。

赤ブドウで, 全 flavonol に対し, kaempferol glucoside $5 \%$, quercetin glucoside (isoquercitrin) $50 \%$, quercetin glucuronoside $35 \%$, myricetin glucoside $15 \%$ であり, 白ブドウでは夫タ， $10 \%, 55 \%, 35 \%, 0$ \%である。

BOURZEIX ${ }^{43)}$ によればブドウ酒中の全 flavonol は 37 〜 $97 \mathrm{mg} / l$ なる值をだしている。

Flavone については WAGNER ら44)がブドウの葉か 5 vitexin (8-C- $\beta$-D-glucopyranosyl-5,7,4'-trihydroxy -flavone), isovitexin (6-C- $\beta-11)$, orientin (8-C- $\beta$ D-glucopyranosyl-5, 7, $3^{\prime} 4^{\prime}$-tetrahydroxyflavone), isoorientin (6-C- $\beta-" \prime)$ を見出している。

\section{III. ブドウ酒醇造とフェノール化合物}

フェノール化合物の大部分はブドウ果粒の固形物（果 皮, パルプ, 種子）に存在するので, それらからの溶出の 度合によってブドウ酒中の total phenol 含量に差を生 ずる。第 6 表 ${ }^{46)}$ 扩よび第 7 表 ${ }^{46)}$ とブドウの各部の tannin
第 6 表 ${ }^{45)}$ ブドウの各部分のタンニン量

\begin{tabular}{cc|c|c|c|c}
\hline & \multicolumn{2}{|c|}{ tannin \% } & \multicolumn{2}{c}{ tannin $\mathrm{kg} / 100 \mathrm{~kg}$} \\
\cline { 3 - 6 } & $\begin{array}{c}\text { Chasselas } \\
\text { doré }\end{array}$ & Pinot noir & $\begin{array}{c}\text { Chasselas } \\
\text { doré }\end{array}$ & Pinot noir \\
\hline 種 & 子 & 5.2 & 6.4 & 0.17 & 0.26 \\
果 & 梗 & 3.2 & 3.1 & 0.12 & 0.11 \\
果 & 皮 & 0.6 & 1.7 & 0.05 & 0.10 \\
\hline
\end{tabular}

第 7 表 ${ }^{46)}$ 発酵前後の各部分のタンニン含量*

\begin{tabular}{|c|c|c|c|c|c|}
\hline & & & 果 & 果 & 種 \\
\hline 発 & 醂 & 前 & 3.17 & 3. 81 & 5.18 \\
\hline 発 & 醇 & 後 & 2.69 & 3.27 & 3.66 \\
\hline
\end{tabular}

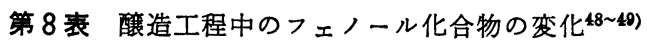
(Müller-Thurgau 種)

\begin{tabular}{|c|c|c|c|c|}
\hline $\mathrm{mg} / \mathrm{l}$ & 㩁 汁 & $\begin{array}{l}\text { 遠心分離 } \\
\text { 後 }\end{array}$ & 発醉後 & $\begin{array}{l}\text { オり引き } \\
\text { 後 }\end{array}$ \\
\hline total phenol & 320 & 300 & 250 & 210 \\
\hline $\begin{array}{l}\text { cyanidin } \\
\text { catechin }\end{array}$ & $\begin{array}{r}80 \\
410\end{array}$ & $\begin{array}{r}40 \\
390\end{array}$ & $\begin{array}{r}30 \\
200\end{array}$ & $\begin{array}{r}30 \\
170\end{array}$ \\
\hline
\end{tabular}

含量と発酵前後の値を示した。

白ブドウ酒のよらに搾汁発酵を行なったものは total tannin が少なく，さらに発醭前のオリ引とか 遠心分離 して固液分離したものはより少ない。しかし，白ブドウ 酒でも“かもし”操作をしたものは, 固形物からの溶出

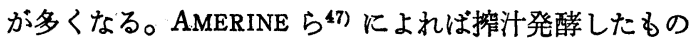
は, total phenol が 300 700 mg/l であるが，かもし 発酵すれば $1,200 \mathrm{mg} / \mathrm{l}$ になる。

第8表は total phenol の他に, anthocyanogen から の cyanidin, および vanillin 反応性の flavanol (catechins）の変化を示したものである ${ }^{48,49) 。 ~}$

Total phenol 量とついては直接 Folin-Cincalteu 法 で測定した場合は酵母の生産物である tyrosol が入って くるし, cafferoyl 化合物の值も大きい。白ブドウ酒で は $1 / 2$ が cafferoyl tartrate と hydroxycinnamate で, 1/4 が tyrosol, その他の phenol である。 赤ブドウ酒では色と渋味が重要である。この場合はか るし発酵であるから phenol 化合物は多くなり, 果皮か らの色素, 種子からの tannin の溶出がある。

この溶出は種々の条件によって左右される。

（1）発酵温度：OUGH 5 ${ }^{49}$ によれば, 同一 alcohol 含量で, $53^{\circ} \mathrm{F}(168 \mathrm{hrs})$ の場合 total phenol は 1,300 $\mathrm{mg} / l ; 68^{\circ} \mathrm{F}(108 \mathrm{hrs})$ では $1,900 \mathrm{mg} / l ; 85^{\circ} \mathrm{F}(72 \mathrm{hrs})$ では $2,500 \mathrm{mg} / \mathrm{l}$ で明らかに温度の高い方が total phenol の溶出が早い。

（2）発酵期間：BERG ら ${ }^{50)}$ によれば赤色素の溶出は 平均 $84 \mathrm{hrs}$ で最高となり, total phenol は $1,420 \mathrm{mg} / l$ で, $110 \mathrm{hrs}$ で $1,710 \mathrm{mg} / \mathrm{l}$ に達する。つまり, 赤色素 の溶出はより早く, その他の tannin は遅く溶出する。 
搾酒までの期間は Bourgogne で 5 6 日, Bordeaux で 8〜15 日温暖地方では 2〜3 日といわれる。

(3) Alcohol 濃度 : BERG ら 順次添加して $8.3 \%$ にした場合, $60 \mathrm{hrs}$ で total phenol $1,240 \mathrm{mg} / l$ であるが，一方発酵で $9.2 \%$ alcohol となっ た場合 $60 \mathrm{hrs}$ では色調は同様でも total phenol は $1,020 \mathrm{mg} / l$ と少なかった。また alcohol が $3 \%$ 生成す る頃に 80\% の anthocyanin が溶出し, alcohol 6\% で は殆んど溶出した。

（4）果梗：果梗を一諸に発酵させれば total phenol は増加する。増加率は $124 \sim 136 \%$ で，量的には果梗な しでは $1,105 \mathrm{mg} / l$ のものが, 果梗入りで $1,522 \mathrm{mg} / l$ になる。SUDRAUD ${ }^{52)}$ は果梗は褐変を促進することを示 した。

Leucoanthocyanin そついて RIBEREAU-GAYON ら ${ }^{\text {83) }}$ は果汁十果皮で $1,300 \mathrm{mg} / l$, 十種子で $2,200 \mathrm{mg} / l$, さ らに果梗を加えると $3,700 \mathrm{mg} / \mathrm{l}$ に増加するとした。

（5）攬汼：発酵が始まると果帽を生ずるが，これを 毎日 2 回液中に沈める操作をすると溶出が早くなる。し たがって循環式も早いことになる。

(6) $\mathrm{SO}_{2}: \mathrm{SO}_{2}$ は色素と phenol 化合物に大きな影 響を与える。適度の $\mathrm{SO}_{2}$ 量の存在はこれらの溶出を促 進する。たとえば $\mathrm{SO}_{2} 100 \mathrm{ppm} て ゙$ total phenol は $1,200 \mathrm{mg} / \mathrm{l}$ となるが, $\mathrm{SO}_{2}$ 無添加では $1,120 \mathrm{mg} / \mathrm{l}$ に 止まる。また anthocyanin では $100 \mathrm{mg} / l$, anthocyanogen では $760 \mathrm{mg} / \mathrm{l}$ になるが, $\mathrm{SO}_{2}$ 無添加では夫々 $26 \mathrm{mg} / l, 320 \mathrm{mg} / l$ と減少する。

$\mathrm{SO}_{2}$ は色素と結合し一時的退色を起すが, 後に復色す る。phenol とも結合しこれらの酸化を妨げる。また 同時に phenol oxidase を阻害する。

（7）新技術：破さいマストを $50 \sim 60^{\circ} \mathrm{C}$ に 15 分内 外加熱して, 色素拉よび tannin を溶出させ, 㩁汁して 発酵させる方法が一部で行なわれている。この方法の良 否について両論があるが, マストの管理は容易になる。

また, carbonic-maceration と称して, $\mathrm{CO}_{2}$ で空気を 置换してかもす方法が開発されている。

これらの方法は, oxidase の阻害並びに酸化防止とも なり,ひいては $\mathrm{SO}_{2}$ の削減にもなる。

\section{IV. ブドウ酒のフェノール化合物の分析法}

\section{(1) Total phenol (第 9 表):}

Löwenthal-Neubauer 法 ${ }^{54)}$ が基本的に利用される。 これは alcohol を除去後, indigo-carmine を用いて $\mathrm{KMnO}_{4}$ で滴定する。この際, 活性炭で処理したものと しないるのとの差を求める ${ }^{55)}$ 。

最近では Folin-Denis 法 ${ }^{66)}$ が利用され; Folin-Cio-
第 9 表 Total phenol 量54)

\begin{tabular}{cr|r|rr}
\hline \multirow{2}{*}{ ブドウ酒のタイプ } & \multicolumn{3}{|c}{ Total phenol, $\mathrm{mg} / \mathrm{l}$} \\
\cline { 2 - 4 } & \multicolumn{1}{|c|}{ 籍 } & 柬 & 平 & 均 \\
\hline 白, & table & $40 \sim 1300$ & 360 \\
赤, table & $190 \sim 3800$ & 2000 \\
白, dessert & $100 \sim 1100$ & 350 \\
赤, dessert & $400 \sim 3300$ & 900 \\
\hline
\end{tabular}

calteu 試薬が用いられる。SINGLETON ら ${ }^{57)}$ はこの方法 をブドウ酒に応用している。しかしこれらの方法は tyrosol b測定值に入ってくることに注意を要する。 tyrosol を別に定量するには大塚ら ${ }^{58)}$ の中性下で酢酸エ チルで抽出する分別法が応用でさる。

（2）色秦

（a）ブドウの色素：果皮のみをとり，乾燥して乳鉢 ですりつぶし, 酢酸メタノールで抽出する。Wax その 他を除いてメタノール溶液とする。これを 2 次元薄層ク ロマト (TLC) にかける。溶媒は butyl formate : formic acid : water $(7: 2: 1)$ 执よび $n$-pentanol : acetic acid : water (2: 1:1) を用いる。測定はデンシトメー ター $(525 \mathrm{~nm})$ で行な $5^{59,60)}$ 。

(b) anthocyanins

RIBEREAU-GAYON 5 ${ }^{61,62)}$ の方法によれば、ブドウ酒 を塩酸酸性 $(\mathrm{pH}<1)$ と緩衝液 $(\mathrm{pH} \mathrm{3.5)} \mathrm{とで} 520 \mathrm{~nm}$ の吸光度の差より算出する $\mathrm{pH}-\mathrm{shift}$ 法と, $\mathrm{NaHSO}_{3}$ 液 を加えた際の $520 \mathrm{~nm}$ の吸光度の差から算出する bisulfite bleaching 法とがある。Standard は cyanidin を用いる。

（c） diglucoside の定量（OIV 法）

Malvidin-diglucosideを測定することにより,vinifera 以外の原料を用いたかとうかの判定の目安にする。この 方法は malvidin-diglucoside がアルコール性アンモニ アの存在下で diazo 化し, このものが特異的蛍光をもつ ことに基ついている68)。

この他に TLC 法 ${ }^{64,65)}$, カラムクロマト法66) 等があ る。

(3) Flavonoids および nonflavonoid phenols:

5,7-dihydroxy をむつ flavonoid は formaldehyde と 反応して methylol 誘導体を形成する。このことを利用 して formaldehyde の反応の前後の Folin-Ciocalteu 值 の差から算出する ${ }^{67)}$ 。

(4) Hydrolyzable tannin phenols

Cinchonine sulfate の添加で沈でんする性質を利用す る68)。Gallic または ellagic acid との糖エステル, 高 級アルニールとのエステル等も混入する。

(5) Catechins

Phloroglucinol 型の flavonoids が vanillin と反応し 
て赤登色の色素を形成する性質を利用した方法であ る69)。この場合，4-keto 化合物は反応しない。

(6) Anthocyanogens (leucoanthocyanidins)

無機酸の存在下で加熱すると flavan-3,4-diols は anthocyanidins となって赤色となる。これを $550 \mathrm{~nm}$ で測定する70)。

(7) Non flavonoid phenols

trimethylsilyl 誘導体としてガスクロマトで測定す る $^{71)}$ 。

（8）色度および褐変度：

OUGH ら ${ }^{72)}$ は OD $\mathrm{OD}^{420} \mathrm{OD}^{520}$ の和を色度としている。 またこの比を褐変指数としている。SUDRAUD ${ }^{78)}$ は 420/ 520 比が，若いブドウ酒では約 $0.7,50$ 年物では 1.7 位であることを示している。

\section{文 献}

1) V.L. Singleton \& P. Esau : Phenolic Substances in Grapes and Wine, and Their Significance, 1969, Academic Press.

2) G. Guimberteau et al.: Ann. Fals. Exp. Chem., 54, 330 (1961)

3) P. RIBÉREAU-GAYON : Compt. rend., 256, 4108 (1963)

4) P.G. PIFFERI : Vitis 5(1), 24 (1965)

5) F.W. Traphagen et a1.: J. Am.Chem.Soc., 25, 242 (1903)

6) A.D. WebB etal.: Anal.Chem., 24, 1944 (1952)

7) K. HENNIG \& R. BURKHARDT : Naturwiss., 44, 328(1957); Weinb. u.-Keller, 4, 374 (1957) ; 5, 542, 593 (1958); Am. J. Enol. Vitic., 11, 64 (1960)

8) V.L. Singleton et al.: Am.J.Enol.Vitic., 17, 206(1966)

9) S.V. DuRmishidze : Dubil'nye Veshchestva i Antotsiany Vinogradnoi Lozi i Vina, p.323, Izda. Akad. Nauk, USSR, Moscow.

10) R.K. Ibrahim et al.: Arch. Biochem. Biophys., 87, 125 (1960)

11) E. SONDEHEIMER : Arch. Biochem. Biophys., 74, 131 (1958)

12) Eva.W. Jurics : $C$. $A$., 68, 76955 (1968)

13) J. MASQUelier \& R. RiccI : p. 13, Singletons' Book.

14) E.F. Kohman \& N.H. SANBoRN : Ind. Eng.Chem., 23, 126 (1931)

15) J. CARLes et a1.: Compt. rend., 247, 2181 (1958)

16) J. Delmas et al.: Ann. Agron., 14, 951 (1963)

17) W.M. KLIEwer : Plant Physiol., 41, 923 (1966)

18) P.C. Pifeeri : Ind. Agrar, 4, 475 (1966)

19) R. BURKHARDT : Mitt. Klostern., 15 A, 80 (1965)

20) P. RibÉREAU-Gayon : Compt. rend., 260, 341 (1965)

21）大塚謙一ら：農化，陆演， 1970.

22) S.S. Chaudhary et al.: Am. J. Enol. Vitic., 19, 6(1968)

23) P. Ribíreau-Gayon \& J.C. SAPIS : Compt. rend., 261, 1915 (1965)

24) J. Lavollay et al.: Compt.rend., 218, 82 (1944)

25) P. Ribereau-Gayon \& E. StONestreet : Deut.Lebensm. Rds., 62, 1 (1966)

26) O. Rosenheim : Biochem. J., 14, 178 (1920)

27) J. LABORDE : Compt. rend., 147, 753 (1908)

28) R. Combes : Compt. rend., 175, 58 (1922)

29) J. MASQUelier \& G. PoIn : Bull. Soc. Pharm. Bordeaux, 95, 6 (1956)

30) P. Ribéreau-Gayon : Compt. rend. Acad. Agr., 43, 197, 596, 821 (1957)

31) J. Ribŕrfau-Gayon et a1.: Am.J.Enol.Vitic., 9, 1(1958)
32) M.A. Joslyn \& H.F.K. Dittmar : Mitt. Klostern., 17 (2), 92 (1967)

33) P. Ribéreau-Gayon \& E. Stonestreet : Chim. Anal., 48, 188 (1966)

34) K. FReUdenberg : Die Chemie der natürlichen Gerbstoffe, Berlin 1933, J. Springer.

35) R. WILlSTätTer \& E. H. Zollinger : Ann.Chem. Liebigs 408, 83 (1915); 412, 113 (1916)

36) L.F. Levy et al.: J. Chem. Soc., 1931, 2701 (1931)

37) P. Ribúreau-Gayon : Compt. rend. Acad. Agr., 39, 800 (1953)

38) L.F. ChEN \& B.S. LUH : J. Food Sci., 32, 66 (1967)

39) R.F. Albach et al.: Am. J. Enol. Vitic., 10, 164 (1959)

40) B. L. Williams \& S. H. Wender : J.Am. Chem. Soc., 74, 4372 (1952)

41) J. Masquelier \& G. Point : Bull. Soc. Pharm. Bordeaux 92, 33 (1954)

42) P. Ribŕreau-Gayon : Ann. Physiol. Végétale 6, 119, 211, 259 (1964) ; Compt. rend., 258, 1335 (1964)

43) M. Bourzeix : Ann.Technol.Agr. 16, 349 (1967)

44) H. WAGNER et a1.: $Z$. Naturforsch., B 22, 988 (1967)

45) L. Benvegnin et al.: Traité de Vinification, Lausanne (1951), Ref. M. A. AmErine et al.: Technology of Wine Making, p.107 (1971)

46) C. Neubauer : Annalen der Önologic, 2, 23 (1872) Ref. E. VOGT : Weinechemie u. Weinanalyse, p. 48.

47) M. A. AMERINe \& A. J. WINKLER : Hilgardia 15, 493(1944)

48) K. WUCHERPFENNIG et al.: $Z$. Lebensm.-Untersuch., 124, $22(1963)$

49) C.S. OUgh \& M. A. AMERINe : Am. J. Enol. Vitic., 11, 5 (1960)

50) H.W. Berg \& M. Akiyoshi : Am. J. Enol. Vitic., 7, 84 (1956)

51) H.W. Berg \& M. AKIYoshi : Food Res., 4, 373 (1957); 23, 511 (1958)

52) P. Sudraud : Ann. Technol. Agr., 7, 203 (1958)

53) P. Ribéreau-Gayon \& E. Stonestreet : Compt. rend. Acad. Agr., 50, 662 (1964)

54) J. Löwenthal : $Z$. Anal. Chem., 16, 33 (1877)

55) M.A. Amerine C.S. Ough : Wine and Must Analysis, p. 64 (1974)

56) O. Folin \& W. Denis : J.Biol.Chem., 12, 239 (1912)

57) V.L. Singleton \& J.A. Rossi : Am. J. Enol. Vitic., 16 , 144 (1965)

58）大塚䛵一ら：酸協，62，72(1967)

59) W. ANderson et a1.: Phytochem., 9, 1569, 1579 (1970)

60) R.A. Fong et a1.: Am. J. Enol. Vitic., 22, 150 (1971)

61) P. Ribíreau-Gayon \& D. Nedeltchev : Ann. Tech. Agr., 14, 321 (1965)

62) P. Ribéreau-Gayon \& E. Stonestreet : Bull. Soc. Chim. Fr., 2649 (1965)

63) H. BIEBER : Deut. Lebensm. Rds., 63, 44 (1967)

64) L. Diebner et al.: Ann. Tech. Agr., 13, 359 (1964)

65) H. SchmidT-HebBel et a1.: Z. Lebensm. Untersuch., 137 , 169 (1968)

66) G. Hrazdina : J. Agr. Fd. Chem., 18, 243 (1970)

67) T.E. Kramling \& V.L. Singleton : Am. J.Enol.Vitic., 20, $86(1969)$

68) C. PERI \& C. POMPEI : Am.J.Enol.Vitic., 22, 55 (1971)

69) C. POMPEI \& C. PeRI : Vitis, 9, 312 (1971)

70) C. POMPEI et al.: Ann. Tech.Agr., 20, 21 (1971)

71) E. N. Christensen \& A. CAPUTI : Am. J.Enol.Vitic., 19, 238 (1968)

72) C.S. Ough \& M.A. Amerine : Am. J. Enol. Vitic., 13, 181 (1962)

73) P. Sudraud : Am. Tech. Agr., 7, 203 (1958)

文献調査飞㙝力された户塚昭氏に感謝する 